\title{
PENGARUH PERBEDAAN LAMA EKSTRAKSI TEH PUTIHDENGAN MENGGUNAKAN METODE MICROWAVE ASSISTED EXTRACTION (MAE)
}

\author{
Asri Widyasanti ${ }^{1}$, Heri Aryadi ${ }^{1}$, Dadan Rohdiana ${ }^{2}$ \\ ${ }^{1}$ Departemen Teknik Pertanian dan Biosistem, Fakultas Teknologi Industri Pertanian, \\ Universitas Padjadjaran, Jalan Bandung-Sumedang km 21, Jatinangor, 40600 \\ ${ }^{2}$ Pusat Penelitian Teh dan Kina, Gambung \\ Email: asri.widyasanti@unpad.ac.id
}

\begin{abstract}
ABSTRAK
Teh putih merupakan teh yang diolah dari pucuk (peko) Camellia sinensis melalui proses pelayuan dan pengeringan. Proses pengolahan yang minim tersebut diduga menyebabkan kandungan polifenolnya lebih tinggi dibandingkan dengan jenis teh lainnya. Tujuan dari penelitian ini adalah untuk mengetahui pengaruh lama ekstraksi yang berbeda terhadap sifat fisikokimia ekstrak teh putih dengan menggunakan Microwave Assisted Extraction (MAE). Lama ekstraksi yang digunaka yaitu 2, 4, 6, dan 8 menit dengan level daya $70 \%(490 \mathrm{~W})$. Metode yang digunakan adalah percobaan laboratorioum dengan analisis deskriptif. Parameter yang diuji dilakukan meliputi rendemen total, kadar sisa pelarut, bobot jenis, warna, dan kadar polifenol. Hasil penelitian menunjukan perbedaan lama ekstraksi pada proses ekstraksi mempengaruhi nilai rendemen ekstraksi dan mutu ekstrak dengan penggunaan lama ekstraksi 8 menit sebagai perlakuan terbaik dengan nilai rendemen total sebesar 29,14\%; nilai rendemen filtrasi $65,79 \%$; rendemen evaporasi sebesar 7,60\%; bobot jenis ektrak sebesar 1,1028 dan kadar polifenol sebesar $63,60 \%$. hasil menunjukan nilai yang lebih baik dibandingkan dengan maserasi dengan rendemen total hasil maserasi $24,11 \%$; nilai rendemen filtrasi $41,57 \%$; rendemen evaporasi sebesar 4,45\%; bobot jenis ekstrak sebesar 1,1008 dan kadar polifenol sebesar 48,35\%. Dapat dilihat dari hasil penelitian ini menunjukan terdapat pengaruh gelombang mikro pada sifat fisikokimia ekstrak teh putih yang menunjukan pengaruh terbesarnya terdapat pada penggunaan level daya $70 \%$ dan lama ekstraksi 8 menit.

Kata kunci-ekstrak; lama ekstraksi; microwave assisted extraction; teh putih
\end{abstract}

\section{PENDAHULUAN}

Teh putih merupakan teh yang diolah dari pucuk (peko) Camellia sinensis melalui proses pelayuan dan pengeringan. Proses pengolahan yang minim tersebut diduga menyebabkan kandungan polifenolnya lebih tinggi dibandingkan dengan jenis teh lainnya (Balittri, 2013). Teh dianggap menyehatkan karena mengandung polifenol, vitamin, mineral, alkaloid, asam amino, dan minyak atsiri. Meskipun lebih langka dan mahal daripada teh hijau dan teh hitam, teh putih dikonsumsi karena kemungkinan implikasinya bagi kesehatan. Teh putih dan hijau dianggap sangat bermanfaat karena memiliki jumlah dari epigallocatechin-gallate (EGCG) yang tinggi, sebagai polifenol biologis aktif (Ho, et al, 2009). Polifenol merupakan komponen kimia yang mempunyai aktivitas antioksidan karena mendonorkan elektron kepada radikal bebas (Suzuki et al, 2003).

Teh putih berpotensi dikembangkan sebagai sumber antioksidan alami. Antioksidan alami merupakan antioksidan yang berasal dari bahan-bahan alam. Penelitian Rohdiana dkk. (2013) mengenai pengaruh suhu air seduhan dan lama penyeduhan menujukkan bahwa seduhan teh putih memiliki aktivitas antioksidan dengan nilai tertinggi $\mathrm{IC}_{50}$ yaitu $35,41 \mathrm{~g} / \mathrm{ml}$.

Selain digunakan dalam bentuk seduhan, teh putih juga dapat dikembangkan dalam bentuk ekstrak. Kandungan polifenol yang berisifat antioksidan pada teh putih dapat melindungi kulit manusia dari sinar ultraviolet yang dapat menyebabkan kanker kulit. Selain itu, ekstrak teh putih ini juga telah digunakan sebagai bahan campuran produk-produk pangan. Tetapi sampai sejauh ini masih minimnya data-data ilmiah yang menjelaskan tentang aktivitas antioksidan dari ekstrak teh putih ini sehingga perlunya dilakukan penelitian ini.

Sistem ekstraksi efisien yang dapat digunakan pada proses ekstraksi produk pengan salah satunya adalah ektraksi berbantu gelombang mikro. Ekstraksi menggunakan gelombang mikro (MAE) merupakan ekstraksi yang memanfaatkan radiasi gelombang mikro untuk mempercepat ekstraksi 
selektif melalui pemanasan pelarut secara cepat dan efisien (Jain et al., 2009). Menurut beberapa hasil penelitian, MAE meningkatkan efisiensi dan efektifitas ekstraksi bahan aktif berbagai jenis rempahrempah, tanaman herbal, dan buah-buahan (Calinescu et al., 2001). Kelebihan MAE adalah waktu ekstraksi dan kebutuhan pelarut yang relatif rendah dibanding ekstraksi konvensional (Mandal et al., 2007) Sehingga pada penelitian ini bertujusn untuk mempelajari pengaruh lama ekstraksi yang berbeda terhadap sifat fisikokimia ekstrak teh putih dengan menggunakan Microwave Assisted Extraction (MAE).

\section{METODOLOGI PENELITIAN}

\section{A. Alat dan Bahan}

Alat yang digunakan pada penelitian ini ialah oven untuk mengukur kadar air, microwave untuk mengekstrak, rotary evaporator untuk memisahkan pelarut dengan bahan dan kertas saring untuk menyaring pelarut dari kontaminasi bubuk teh. Bahan penelitian yang digunakan sebagai bahan baku adalah teh putih Gamboeng dari Pusat Penelitian Teh dan Kina Gambung, Bandung. Pelarut yang digunakan selama proses ekstraksi yaitu etanol 96\%. Bahan pendukung/analisis untuk mengukur determinasi kandungan total polifenol meliputi aquades, etanol $95 \%$, reagen Folin-Ciocalteu, $\mathrm{Na}_{2} \mathrm{CO}_{3}$ $7,5 \%$ dan asam galat sebagai standar.

\section{B. Metode Penelitian}

Metode penelitian yang digunakan adalah metode eksperimen laboratorium dengan menggunakan analisis deskriptif. Penelitian ini menggunakan satu jenis pelarut yang digunakan pada proses microwave assisted extraction (MAE) yaitu etanol 96\%. Variabel yang diukur pada penelitian ini meliputi, kenaikan suhu, sedangkan parameter yang dihitung terdiri dari rendemen parsial dan rendemen total. Adapun parameter mutu ekstrak teh putih yang dianalisis terdiri dari bobot jenis, dan kadar sisa pelarut. Pada penelitian ini juga dilakukan analisis kadar polifenol yang terdapat pada hasil ekstraksi teh putih. Perlakuan perbedaan lama ekstraksi mengunakan variasi waktu ekstraksi dari 2, 4, 6 , dan 8 menit dengan level daya yang digunakan sebesar $70 \%$.

\section{Prosedur Percobaan}

a. Persiapan Bahan Baku

Sebelum dilakukan proses ekstraksi, daun teh digiling untuk mengecilkan ukuran kemudian dilakukan pengayakan agar didapatkan bubuk teh yang seragam, bubuk teh yang digunakan adalah bubuk yang lolos tyler sieves ukuran 18 mesh.

\section{b. Ekstraksi Teh Putih}

Proses pembuatan ekstraksi teh putih dilakukan menggunakan metode microwave assisted extraction (MAE) dan maserasi tunggal sebagai kontrol terhadapt metode MAE. Bubuk teh putih lolos mesh 18 ditimbang sebanyak 10 gram, kemudian dimasukkan kedalam breaker glass. 10 gram bubuk teh putih dalam breaker glass dicampurkan dengan pelarut etanol $200 \mathrm{~mL}$. Perbandingan yang digunakan adalah 1:20 (b/v). Selanjutnya dilakukan proses ekstraksi bahan dengan pelarut didalam microwave dengan lama 2, 4, 6, dan 8 menit dengan level daya $70 \%$. Setelah itu dilanjutkan pada proses penyaringan dengan menggunakan kertas saring Whatmen no.42 untuk memisahkan filtrat dengan ampas. Kemudian dilakukan proses evaporasi untuk didapatkan ekstrak kental yang diap diuji.

Perlakuan kontrol dilakukan dengan maserasi tunggal dengan cara gelas beaker berisi bubuk teh putih dan pelarut etanol diletakan di atas hotplate magnetik stirrer dengan waktu yang berbeda, yaitu pada suhu $65^{\circ} \mathrm{C}$ serta waktu pada 2, 4, 6, dan 8 menit. Campuran bubuk teh putih dan pelarut disaring menggukan penyaringan vaccum dengan kertas Whatman no.42. Hasil saringan ini berupa ampas dan maserat dari pelarut etanol. Ampas ditimbang dan maserat diukur volumenya. Ekstrak dari pelarut dikentalkan dengan menggunakan rotary vacuum evaporator dengan suhu $\pm 40^{\circ} \mathrm{C}$ selama 2-3 jam. Adapun diagram alir ekstraksi teh putih metode microwave assisted extraction (MAE) dan maserasi tunggal disajikan pada Gambar 1. 


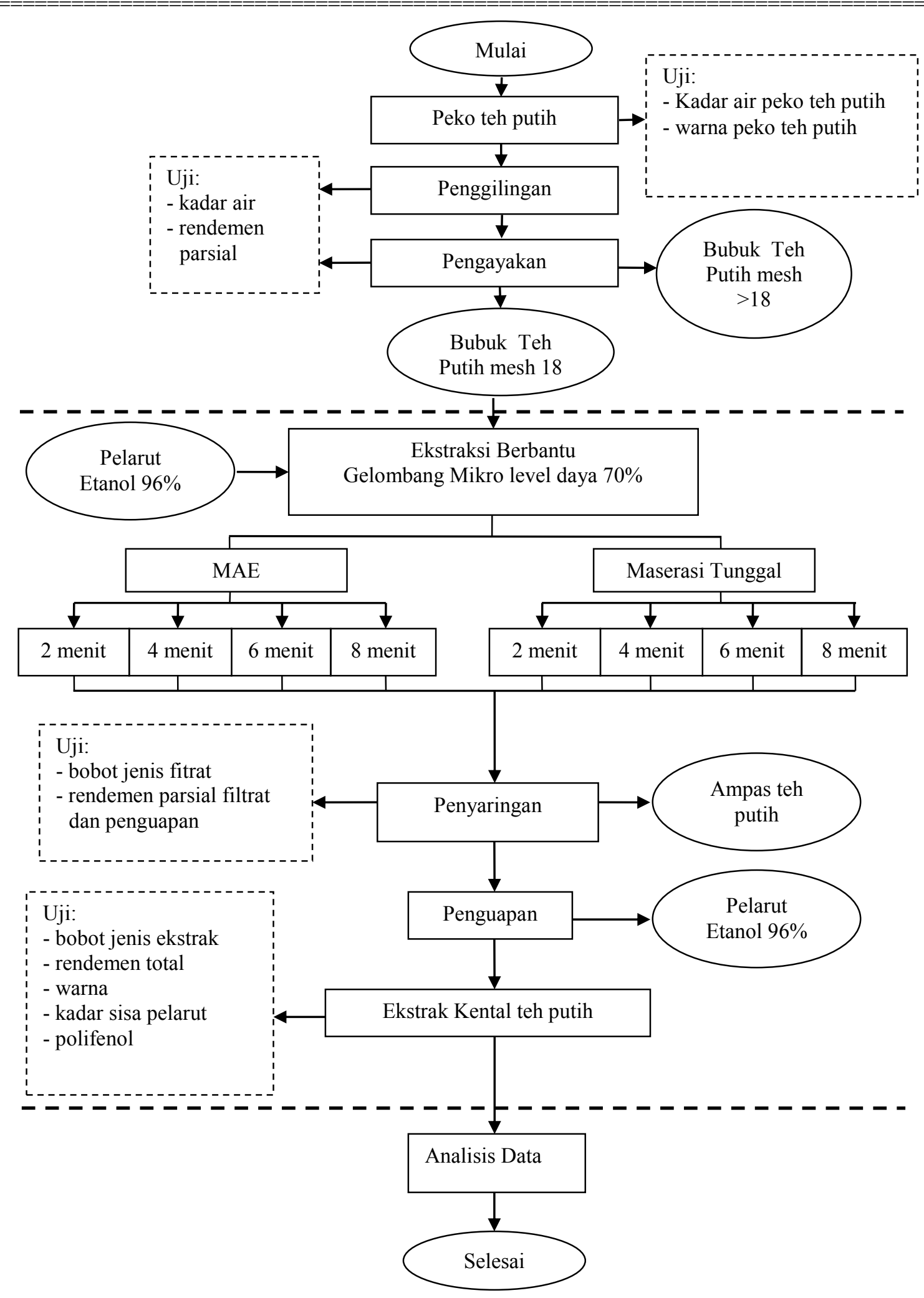

Gambar 1. Diagram alir ekstraksi teh putih 


\section{HASIL DAN PEMBAHASAN}

\section{A. Kondisi Proses Ekstrak Berbantu Gelombang Mikro}

Pada proses ekstraksi berbantu gelombang micro terdapat pengaruh dari suhu. Suhu yang meningkat dipengaruhi oleh jenis pelarut dan penggunaan rasio perbandingan bahan dan pelarut. Penelitian ini menggunakan jenis pelarut etanol 96\% dengan perbandingan 1:20 (b/v) (Noorhamdani, dkk. 2013). Grafik kenaikan suhu pada setiap lama waktu ekstraksi terdapat pada Gambar 2.

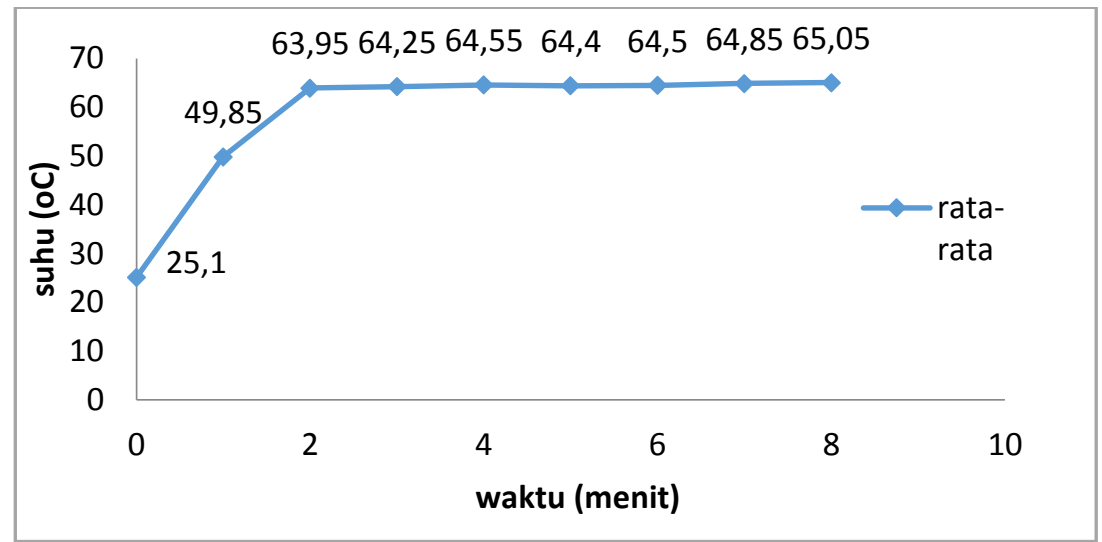

Gambar 2. Kenaikan Suhu Rata-Rata MAE

Berdasarkan Gambar 2, diketahui bahwa semakin lama ekstraksi dilakukan semakin tinggi pula kenaikan suhu yang terjadi selama proses. Kenaikan suhu terendah terjadi pada perlakuan lama waktu 2 menit, yaitu $63,8^{\circ} \mathrm{C}$ dan yang tertinggi terjadi pada perlakuan dengan lama waktu ekstraksi 8 menit, yaitu sebesar $65,1^{\circ} \mathrm{C}$. Dilihat dari gambar 1 kenaikan paling drastis terjadi pada menit pertama proses ekstraksi kemudian pada menit-menit berikutnya kenaikan suhu mulai stabil dan hanya terjadi sedikit kenaikan suhu hal ini dikarenakan pada awal proses ektaksi pelarut masih bersuhu ruang, belum mencapai titik didihnya. Pada waktu yang lebih lama, pelarut mulai mendekati titik didih sehingga kenaikan suhu yang terjadi hanya sedikit demi sedikit.

\section{B. Rendemen Ekstrak Teh Putih}

Rendemen parsial yang dihitung meliputi rendemen penggilingan, rendemen pengayakan, rendemen ekstraksi, rendemen filtrasi, dan rendemen evaporasi. Hasil perhitungan rendemen parsial pertahapan disajikan pada Tabel 1 dan Tabel 2.

Tabel 1. Data Rendemen Persiapan Bahan Baku

\begin{tabular}{cc}
\hline Proses & Rendemen* \pm SD $(\%)$ \\
\hline Penggilingan & $99,88 \pm 0,02$ \\
Pengayakan & $99,73 \pm 0,14$ \\
\hline *Rata-rata tiga kali ulangan &
\end{tabular}

Rendemen pengecilan ukuran diperolah dari proses pengecilan ukuran peko kering teh putih menjadi bubuk teh putih. Berdasarkan hasil analisis diperoleh nilai rata-rata rendemen pengecilan ukuran sebesar 99,88\%. Berkurangnya massa peko kering teh putih disebabkan karena ada sebagian massa yang menempel pada wadah atau terbang pada saat pemindahan hasil penggilingan kedalam plastik pada saat akan ditimbang. Menurut Sharief (2006), teh diperkecil ukurannya untuk mengurangi sifat padat dari bahan dan membantu penetrasi pelarut ke dalam sel tumbuhan sehingga mempercepat pelarutan komponen bioaktif dan meningkatkan rendemen ekstraksi.

Setelah dilakukan penggilingan kemudian dilakukan proses pengayakan. Pengayakan ini berfungsi untuk menyamakan ukuran bubuk teh yang ekstraksi yaitu ukuran bubuk teh yang lolos ayakan 18 mesh. Ukuran partikel bubuk teh untuk mendapatkan nilai polifenol terbaik didapat pada ukuran 18 mesh (Siringo-ringo, 2006). Nilai rendemen pengayakan pada penelitian ini diperoleh sebesar 
$99,73 \%$. Ada massa yang hilang kemungkinan terjadi karena adanya bubuk yang menempel pada wadah.

Tabel 2. Data Rendemen Parsial

\begin{tabular}{crrr}
\hline \multirow{2}{*}{ Perlakuan } & \multicolumn{3}{c}{ Rendemen Parsia* $*$ SD } \\
\cline { 2 - 4 } & \multicolumn{1}{c}{ Ekstraksi MAE } & \multicolumn{1}{c}{ Filtrasi } & \multicolumn{1}{c}{ Evaporasi } \\
\hline MAE 2 & $98,92 \pm 0,29$ & $76,37 \pm 0,46$ & $4,11 \pm 0,38$ \\
MAE 4 & $93,74 \pm 1,04$ & $72,73 \pm 2,66$ & $5,07 \pm 0,41$ \\
MAE 6 & $88,30 \pm 0,36$ & $69,19 \pm 1,24$ & $6,38 \pm 0,73$ \\
MAE 8 & $81,05 \pm 1,32$ & $65,79 \pm 0,84$ & $7,60 \pm 0,63$ \\
Maserasi 2 & $99,90 \pm 0,01$ & $71,83 \pm 1,28$ & $3,25 \pm 0,28$ \\
Maserasi 4 & $99,01 \pm 0,48$ & $61,51 \pm 0,29$ & $3,23 \pm 0,27$ \\
Maserasi 6 & $99,30 \pm 0,53$ & $51,34 \pm 0,94$ & $3,79 \pm 0,39$ \\
Maserasi 8 & $96,62 \pm 0,96$ & $41,57 \pm 1,62$ & $4,45 \pm 0,29$ \\
\hline
\end{tabular}

Berdasarkan data rendemen parsial yang tersaji pada Tabel 2. Nilai rendemen proses ekstraksi mengalami penurunan setiap lama ektraksi bertambah. Semakin lama ekstraksi yang dilakukan maka kenaikan suhu yang terjadi pada sistem semakin besar pula. Kenaikan suhu yang semakin tinggi menyebabkan pelarut pada sistem lebih banyak menguap dan terjadi kehilangan massa.

Pada proses filtrasi, nilai rendemen parsial yang didapat cukup tinggi. Tingginya rendemen penyaringan diduga karena pada proses ini kehilangan massa hanya disebabkan oleh ampas teh putih yang nilainya berkisar antara $22,55 \%-55,05 \%$ serta disebabkan oleh penguapan yang terjadi ketika penyaringan.

Pada proses evaporasi, nilai rendemen yang diperoleh memiliki nilai yang kecil. Rendahnya rendemen evaporasi disebabkan pada proses tersebut hampir seluruh pelarut yang dievaporasi terkondensasi kembali menjadi etanol dan hanya menyisakan ekstrak yang jumlahnya sangat sedikit. Nilai rendemen meningkat sejalan dengan semakin lamanya waktu ekstraksi.

Rendemen total pada penelitian ini merupakan perbandingan antara massa bubuk teh putih dengan massa ekstrak kental teh putih. Berdasarkan hasil analisis diperoleh rata-rata nilai rendemen total pada masing-masing perlakuan dapat dilihat pada Gambar 2.

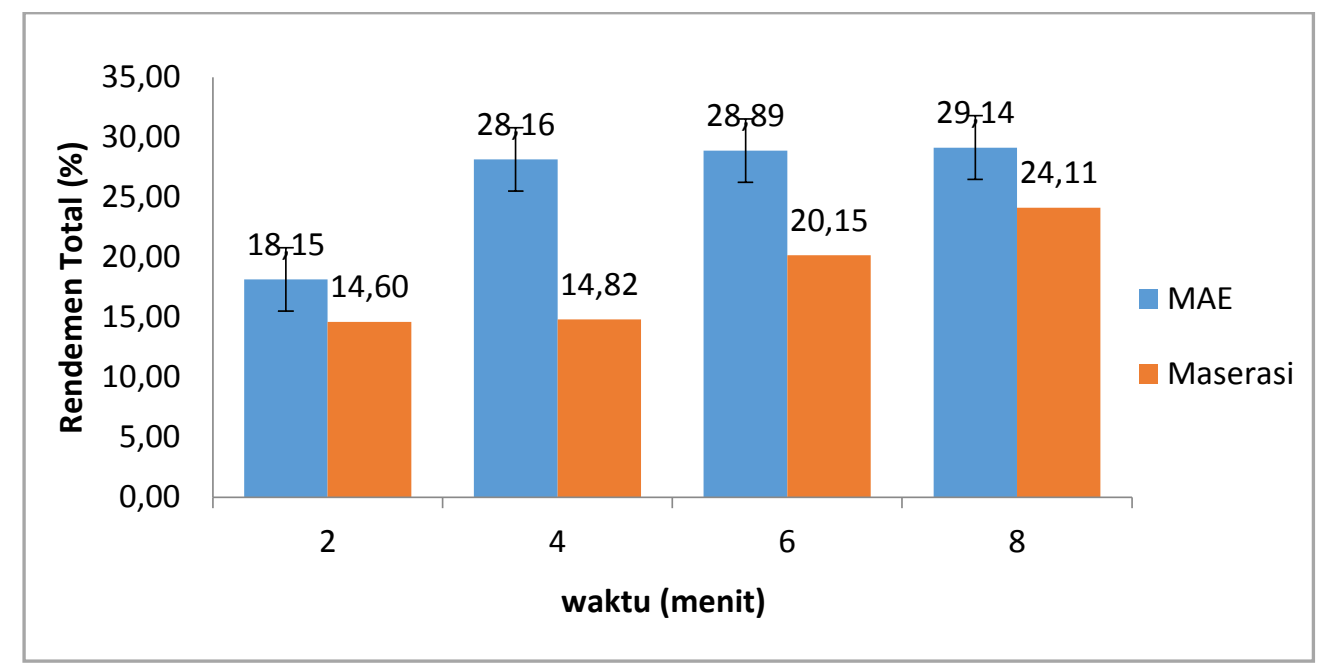

Gambar 2. Rendemen Total

Berdasarkan Gambar 2, terlihat bahwa rendemen total yang dihasilkan semakin meningkat berbanding lurus dengan lama ekstraksi yang digunakan. Dibandingkan dengan perlakuan kontrol yang memiliki nilai tinggi adalah perlakuan utama. Pada lama ekstraksi 2 menit rendemen total sebesar 18,18\% sedangkan maserasi 2 menit memiliki nilai rendemen total yang lebih rendah, yaitu sebesar 14,16\%. Pada lama ekstraksi 4 menit nilai rendemen yang didapatkan sebesar 28,16\% sedangkan pada maserasi dengan lama ekstraksi 4 menit memiliki nilai rendemen total sebesar 14,82\%. Pada lama ekstraksi 6 menit nilai rendemen yang di dapatkan sebesar 28,89\% sedangkan pada maserasi dengan lama ekstraksi 4 menit nilai rendemen totalnya adalah 20,15\%. Kemudian pada lama ekstraksi terlama 
yaitu 8 menit didapatkan nilai rendemen total sebesar 29,14\% sedangkan pada kontrol dengan lama ekstraksi 8 menit didapatkan nilai rendemen total sebesar $24,11 \%$.

\section{Karakteristik Ekstrak Teh Putih \\ a. Kadar Sisa Pelarut}

Pengujian kadar sisa pelarut dilakukan untuk mengetahui banyaknya jumlah pelarut yang masih tersisa atau belum menguap dari ekstrak yang dihasilkan. Berdasarkan hasil pengujian kadar sisa pelarut (Gambar 3) diperoleh rata-rata nilai kadar sisa pelarut terkecil adalah 45,33\%. Nilai kadar sisa pelarut ini tergolong tinggi dan tidak memenuhi standar sisa pelarut yang aman untuk bahan panga maupun farmasi. Tingginya niai kadar sisa pelarut diduga karena penggunaan perbandingan bahan dan pelarut yang digunakan yaitu 1:20.

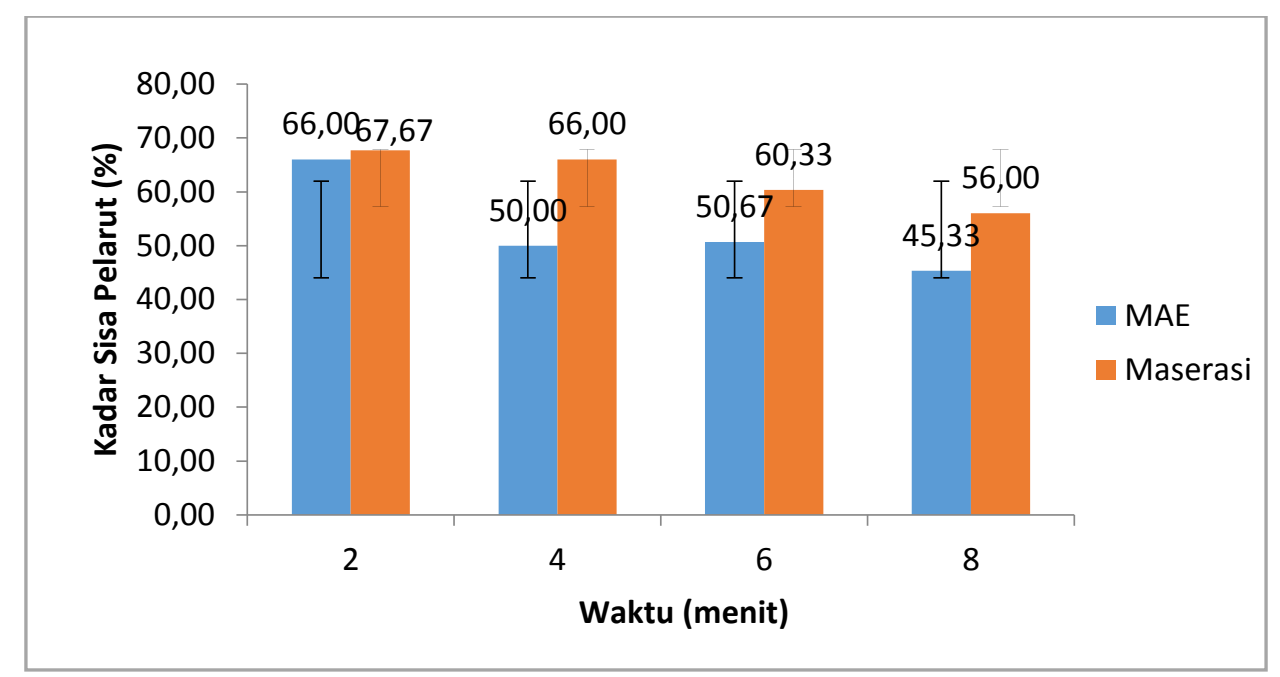

Gambar 3. Nilai Kadar Sisa Pelarut

\section{b. Warna}

Alat yang digunakan pada penelitian ini yaitu Spectrofotometer color flex EZ. Penggunaan alat ini cukup mudah. Sebelum digunakan untuk pengukuran warna sampel, spektrofotometer dikalibrasi dua warna standar hitam dan putih. Kemudian ekstrak teh putih dimasukan kedalam kuvet, lalu kuvet yang terisi ekstrak teh putih diletakan di atas spektrofotometer kemudian ditembakan cahaya dari bagian bawah kuvet hingga diperoleh nilai $\mathrm{L}^{*}, \mathrm{a}^{*}, \mathrm{~b}^{*}, \mathrm{C}$, dan $\mathrm{H}$ seperti yang terlihat pada Tabel 3.

Tabel 3. Data Hasil Uji Warna

\begin{tabular}{ccccccc}
\hline Perlakuan & \multicolumn{4}{c}{ Parameter Warna } & Kromatisitas Warna* \\
\cline { 2 - 6 } & $\mathrm{L}^{*}$ & $\mathrm{a}^{*}$ & $\mathrm{~b}^{*}$ & $\mathrm{C}$ & $\mathrm{H}$ & \\
\hline MAE 2 & 19,15 & 21,99 & 32,32 & 39,37 & 54,28 & Yellow Red \\
MAE 4 & 15,67 & 23,14 & 26,68 & 35,46 & 48,44 & Red \\
MAE 6 & 10,74 & 20,24 & 18,27 & 27,42 & 40,99 & Red \\
MAE 8 & 7,86 & 14,88 & 12,73 & 19,60 & 40,64 & Red \\
Maserasi 2 & 11,66 & 11,90 & 16,97 & 11,66 & 41,20 & Red \\
Maserasi 4 & 11,62 & 11,08 & 16,25 & 19,67 & 55,73 & Yellow Red \\
Maserasi 6 & 9,16 & 13,79 & 15,38 & 20,97 & 42,24 & Red \\
Maserasi 8 & 4,65 & 8,42 & 7,20 & 11,13 & 43,32 & Red \\
\hline
\end{tabular}

Notasi L* menyatakan kecerahan pada ekstrak teh putih. Nilai L* berkisar antara 0 (hitam) hingga 100 (putih) (Suyatma, 2009). Nilai $\mathrm{L}^{*}$ dari ekstrak teh putih dengan menggunakan keempat perbedaan waktu tersebut kurang dari 30, sehingga ekstrak tersebut digolongkan agak gelap. Notasi a* menyatakan warna campuran merah dan hijau. Nilai a* dari 0 sampai 80 maka menyatakan warna merah dan nilai a* dari -80 sampai 0 menyatakan warna hijau (Suyatma, 2009). Pada ekstrak teh putih setiap perlakuan menghasilkan a* bernilai positif yaitu berkisar antara 8,42 sampai 23,14 dan dapat dikatakan 
ekstrak berwarna merah. Ekstrak teh putih dengan perlakuan lama ekstraksi 4 menit memiliki nilai a* tertinggi. Notasi $b^{*}$ menyatakan warna campuran biru dan kuning. Nilai $b^{*}$ dari 0 sampai 70 maka menyatakan warna kuning dan nilai b* dari -70 sampai 0 menyatakan warna biru (Suyatma, 2009). Pada ekstrak teh putih setiap perlakuan menghasilkan $b^{*}$ bernilai positif yaitu berkisar antara 7,20 sampai 32,32 dan dapat dikatakan ekstrak berwarna kuning. Ekstrak teh putih dengan perlakuan lama ekstraksi 2 menit memiliki nilai $b *$ tertinggi.

Nilai Chroma/Saturation adalah derajat intensitas suatu warna untuk mendefinisikan kemurnian suatu warna, baik cenderung kotor (grayish) maupun cenderung dominan (murni). Semakin tinggi nilai chroma (C) maka semakin tegas warna yang diukur. Berdasarkan hasil penelitian didapatkan nilai chorma 4,65 sampai 19,15, dengan nilai C tertinggi terdapat pada ekstrak teh putih perlakuan lama ekstraksi 4 menit.

Nilai Hue mewakili panjang gelombang dari warna yang dominan. Nilai Hue didapatkan dari a* dan $b^{*}$. Nilai Hue ini akan disesuaikan dengan daerah kisaran warna kromatisitas (skala Hutching) seperti yang tersaji pada Tabel 3. Pada penelitian ini nilai Hue rata-rata berkisar antara 40,64 sampai 55,73 sehingga seluruh sampel ekstrak teh putih hasil ekstraksi pada penelitian ini masuk dalam daerah kisaran warna kromatisitas red atau Merah hingga yellow red atau merah kekuningan.

Pada penelitian ini juga dilakukan analisis Total Color Difference (TCD). Nilai TCD dapat dilihat pada Tabel 4. TCD dimaksudkan untuk mengetahui perbedaan warna dari ekstrak dan bubuk teh putih. Selain itu juga nilai TCD menunjukkan pengaruh pengolahan terhadap warna. Nilai TCD yang diperoleh berkisar antara 84,84 - 90,21. Nilai TCD yang cukup besar dari warna ekstrak teh putih terhadap bubuk teh putih, menyatakan bahwa proses ekstraksi yang dilakukan pada teh putih menghasilkan perubahan warna dengan kategori perbedaan sangat besar.

Tabel 4. Nilai TCD

\begin{tabular}{cll}
\hline Perlakuan & TCD & Kategori \\
\hline MAE 2 & $85,46 \pm 1,10$ & Sangat Besar \\
MAE 4 & $86,40 \pm 1,34$ & Sangat Besar \\
MAE 6 & $88,10 \pm 1,77$ & Sangat Besar \\
MAE 8 & $88,61 \pm 0,78$ & Sangat Besar \\
Maserasi 2 & $85,51 \pm 4,04$ & Sangat Besar \\
Maserasi 4 & $84,84 \pm 1,50$ & Sangat Besar \\
Maserasi 6 & $88,66 \pm 3,37$ & Sangat Besar \\
Maserasi 8 & $90,21 \pm 1,04$ & Sangat Besar \\
\hline
\end{tabular}

\section{c. Jenis}

Pengujian nilai bobot jenis ekstrak teh putih menggunakan alat piknometer menghasilkan data seperti yang tertera pada Tabel 5. Perbedaan lama ekstraksi berpengaruh terhadap nilai bobot jenis. Nilai bobot jenis filtrat dan ekstrak menunjukan nilai yang semakin meningkat. Semakin lama ekstraksi dilakukan artinya semakin banyak jumlah komponen yang terekstraksi dari dalam teh putih. Bobot jenis sering dihubungkan dengan fraksi berat komponen-komponen yang terkandung didalamnya.

Tabel 5. Nilai Bobot Jenis

\begin{tabular}{ccc}
\hline \multirow{2}{*}{ Perlakuan } & \multicolumn{2}{c}{ Bobot jenis } \\
\cline { 2 - 3 } & Filtrat & Ekstrak \\
\hline MAE 2 & $0,78 \pm 0,009$ & $1,05 \pm 0,005$ \\
MAE 4 & $0,79 \pm 0,001$ & $1,07 \pm 0,023$ \\
MAE 6 & $0,80 \pm 0,004$ & $1,07 \pm 0,002$ \\
MAE 8 & $0,81 \pm 0,001$ & $1,10 \pm 0,016$ \\
Maserasi 2 & $0,78 \pm 0,009$ & $0,94 \pm 0,008$ \\
Maserasi 4 & $0,79 \pm 0,002$ & $0,96 \pm 0,008$ \\
Maserasi 6 & $0,78 \pm 0,008$ & $1,01 \pm 0,015$ \\
Maserasi 8 & $0,78 \pm 0,009$ & $1,10 \pm 0,004$ \\
\hline
\end{tabular}




\section{d. Kadar Polifenol Ekstrak}

Kadar polifenol merupakan salah satu parameter yang penting dalam mutu teh. Senyawa polifenol ini dapat dimanfaatkan pada industri pangan (makanan atau minuman) dan non-pangan (farmasi atau kosmetik), sebagai bahan yang memberikan keuntungan terkait kesehatan tubuh manusia (Gadkari dan Balaraman, 2015). Kadar polifenol dalam ekstrak teh putih merupakan salah satu parameter dalam mutu sktrak teh putih. Kandungan polifenol ini menggambarkan suatu senyawa yang banyak mengandung gugus fenol. Polifenol dalam teh putih terdistribusi secara luas yang disebut flavonoid. Kandungan utama dalam polifenol adalah flavanol (terutama katekin) (Zhen, 2002). Katekin inilah yang bermanfaat terhadap kesehatan dan optimal terkandung dalam daun yang masih muda.

Penetapan kadar polifenol dilakukan dengan menggunakan reagen Folin-Ciocalteu (FC). Reagen ini mengandung fosfomolibdat-fosfotungstat yang akan mengoksidasi gugus hidroksil dari senyawa fenol menghasilkan senyawa komplek berwarna biru. Reaksi ini berjalan lambat pada suasan asam sehingga pada saat reaksi ditambahkan $\mathrm{Na}_{2} \mathrm{CO}_{3}$ untuk membentuk suasana basa sehingga reaksi dapat berjalan lebih cepat (Agustiningsih, 2010). Pada penelitian ini digunakan asam galat sebagai senyawa fenol pembanding. Asam galat merupakan golongan asam fenolik atau hidroksibenzoat yang mudah diperoleh dalam kondisi stabil dan murni, serta lebih murah dibandingkan dengan senyawa standar lainnya (Lestari, et al., 2015). Kadar polifenol dari setiap perlakuan dan kadar polifenol dari bubuk teh tersaji pada Gambar 4.

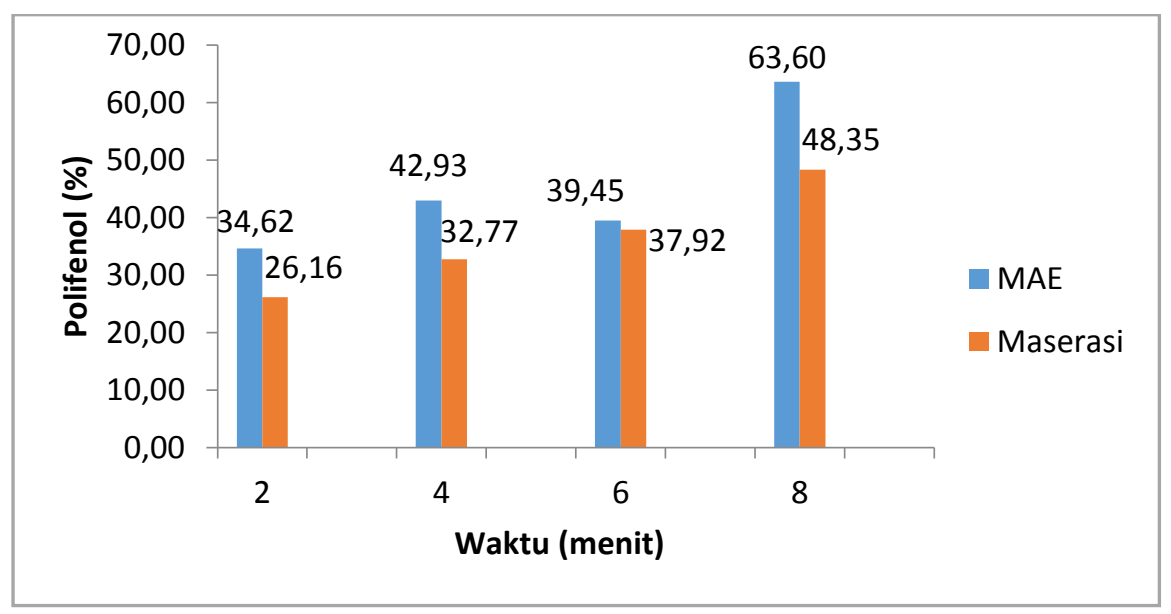

Gambar 4. Kadar Polifenol

Berdasarkan Gambar 4, pengukuran kadar polifenol menunjukan bahwa pada perlakuan lama ekstraksi 8 menit dihasilkan jumlah polifenol yang lebih besar dibandingkan dengan kadar polifenol dari perlakuan lain. Semakin lama waktu ekstraksi yang digunakan makan polifenol yang terekstrak semakin banyak. Dibandingkan dengan perlakuan Maserasi, nilai kadar polifenol pada MAE perlakuan lama ekstraksi 2, 4, 6, dan 8 menit memiliki nilai yang lebih besar. Hal ini menunjukkan bahwa penggunaan ekstraksi berbantu gelombang mikro memberikan hasil yang lebih baik dibandingkan dengan ekstraksi maserasi pada lama ekstraksi yang sama.

Dibandingkan dengan penelitian yang dilakukan Tri halimah, 2017 tentang ekstraksi teh putih dengan menggunnakan gelombang ultrasonik, menggunakan gelombang mikro menghasilkan kadar polifenol yang lebih tinggi dengan penggunaan waktu yang lebih singkan dan jumlah pelarut yang lebih sedikit. Berdasarkan penelitian Halimah (2017) hasil terbaik ada pada perlakuan dengan amplitudo $100 \%$ yaitu sebesar $0,90 \mathrm{mg} / \mathrm{g}$, sedangkan menggunakan gelombang mikro hasil terbaik ada pada perlakuan lama ekstraksi 8 menit yaitu sebesar $1,30 \mathrm{mg} / \mathrm{g}$ jika diubah kedalam persen sebesar $63,60 \%$.

\section{Rekapitulasi Data Terbaik}

Terdapat empat perlakuan yang berbeda pada penelitian ini yaitu perlakuan perbedaan lama waktu ekstraksi yang digunakan yaitu 2 menit, 4 menit, 6 menit, 8 menit. Perbedaan perlakuan ini dilakukan untuk mengetahui lama waktu ekstraksi yang optimal untuk mengekstraksi teh putih dengan metode microwave assisted extraction. Perlakuan yang optimal ini dapat diketahui berdasarkan analisis rendemen dan mutu ekstrak teh putih yang dihasilkan. Rendemen yang digunakan untuk menentukan 
hasil ekstrak teh putih terbaik adalah rendemen total. Sedangkan parameter mutu yang digunakan untuk menentukan ekstrak teh putih terbaik terdiri dari warna, bobot jenis, kadar sisa pelarut, dan kadar polifenol. Untuk rekapitulasi hasil terbaik ekstrak teh putih dapat dilihat pada Tabel 6.

Tabel 6. Rekapitulasi Data Hasil Penelitian

\begin{tabular}{|c|c|c|c|c|c|c|c|c|c|c|c|}
\hline \multirow{2}{*}{\multicolumn{2}{|c|}{ Parameter }} & \multicolumn{4}{|c|}{ Perlakuan (menit) } & \multicolumn{4}{|c|}{ Kontrol (menit) } & \multirow{2}{*}{\multicolumn{2}{|c|}{ Referensi }} \\
\hline & & 2 & 4 & 6 & 8 & 2 & 4 & 6 & 8 & & \\
\hline \multicolumn{2}{|c|}{ Rendemen total (\%) } & 18,15 & 28,16 & 28,89 & 29,14 & 14,60 & 14,82 & 20,15 & 24,11 & $\begin{array}{c}\text { Nilai } \\
\text { Terbesar }\end{array}$ & \multirow{4}{*}{$\begin{array}{l}\text { Chemat } \\
(2011)\end{array}$} \\
\hline \multirow{3}{*}{$\begin{array}{l}\text { Rendemen } \\
\text { parsial } \\
(\%)\end{array}$} & Ekstraksi & 98,92 & 93,74 & 88,30 & 81,05 & 99,90 & 99,01 & 99,30 & 96,62 & \multirow{3}{*}{$\begin{array}{l}\text { Nilai } \\
\text { Terbesar }\end{array}$} & \\
\hline & filltrasi & 76,37 & 72,73 & 69,19 & 65,79 & 71,83 & 61,51 & 51,34 & 41,57 & & \\
\hline & evaporasi & 4,11 & 5,07 & 6,38 & 7,60 & 3,54 & 3,23 & 3,79 & 4,45 & & \\
\hline \multicolumn{2}{|c|}{ Kadar sisa pelarut (\%) } & 66,00 & 50,00 & 50,67 & 45,33 & 67,67 & 66,00 & 60,33 & 56,00 & \multirow{3}{*}{$\begin{array}{l}\text { Nilai } \\
\text { Terbesar }\end{array}$} & \\
\hline \multirow{2}{*}{$\begin{array}{l}\text { Bobot } \\
\text { jenis }\end{array}$} & Filtrat & 0,78 & 0,79 & 0,80 & 0.81 & 0,78 & 0,79 & 0,78 & 0,78 & & \multirow{2}{*}{$\begin{array}{l}\text { Sofyana, } \\
\text { et al. } \\
(2013)\end{array}$} \\
\hline & Ekstrak & 1,05 & 1,07 & 1,07 & 1,10 & 0,94 & 0,96 & 1,01 & 1,10 & & \\
\hline \multirow{6}{*}{ Warna } & $\mathrm{L}^{*}$ & 2,08 & 2,23 & 2,12 & 3,76 & 6,65 & 7,77 & 2,60 & 3,00 & $\begin{array}{c}\mathrm{L}^{*} \\
\text { Terbesar }\end{array}$ & \multirow{5}{*}{$\begin{array}{c}\text { Najib, et } \\
\text { al. } \\
(2017)\end{array}$} \\
\hline & $a^{*}$ & 0,83 & 0,95 & 0,95 & 1,53 & 4,23 & 5,96 & 0,39 & 1,94 & $\begin{array}{c}\mathrm{a}^{*} \\
\text { Terkecil }\end{array}$ & \\
\hline & $\mathrm{b}^{*}$ & 32,32 & 26,68 & 18,27 & 12,73 & 16,97 & 16,25 & 15,38 & 7,20 & & \\
\hline & $\mathrm{C}$ & 1,24 & 1,30 & 1,14 & 2,15 & 7,34 & 10,26 & 0,37 & 2,66 & \multirow{3}{*}{$\begin{array}{c}\mathrm{C} \\
\text { Terbesar }\end{array}$} & \\
\hline & ${ }^{\circ} \mathrm{H}$ & 43,04 & 38,45 & 32,63 & 41,35 & 57,84 & 50,91 & 131,32 & 147,94 & & \\
\hline & TCD & 85,46 & 86,40 & 88,10 & 88,61 & 85,51 & 84,84 & 88,66 & 90,21 & & \\
\hline \multicolumn{2}{|c|}{$\begin{array}{c}\text { Kandungan pilofenol } \\
(\%)\end{array}$} & 34,62 & 42,93 & 39,45 & 63,60 & 26,16 & 32,77 & 37,91 & 48,35 & $\begin{array}{l}\text { Nilai } \\
\text { Terbesar }\end{array}$ & $\begin{array}{c}\text { Sahidi } \\
\text { dan } \\
\text { nazck } \\
(2004)\end{array}$ \\
\hline
\end{tabular}

Berdasarkan Tabel 6, dapat dilihat bahwa rendemen total tertinggi dari kedelapan perlakuan adalah penggunaan lama ekstraksi 8 menit MAE yaitu sebesar 29,14\%, kemudian rendemen tertinggi kedua setelah perlakuan lama ekstraksi 8 menit adalah rendemen perlakuan lama ekstraksi 6 menit MAE yaitu sebesar 28,89\% dan rendemen total terendah adalah rendemen dengan lama ekstraksi 2 menit maserasi yaitu sebesar $14,60 \%$.

Dilihat berdasarkan mutu, dari keempat parameter yang dianalisis, salah satu parameter, yaitu warna menyatakan bahwa perlakuan maserasi yang paling baik. Namun pada parameter warna, nilai a* terbaik dinyatakan pada perlakuan maserasi dengan lama ekstraksi 6 menit, karena ekstrak teh yang diharapkan memiliki nilai a* terkecil. Adapun dua parameter lain yaitu parameter bobot jenis dan kadar polifenol menunjukkan bahwa perlakuan terbaik adalah perlakuan lama ekstraksi 8 menit MAE Sedangkan, parameter kadar sisa pelarut disimpulkan tidak ada perlakuan yang menyatakan hasil terbaik. Hal ini dikarenakan nilai kadar sisa pelarut seluruh perlakuan, memiliki nilai yang sangat tinggi, dan perlu dilakukan proses pemurnian. Sehingga dari hasil rekapitulasi tersebut dapat diambil kesimpulan bahwa perlakuan terbaik pada penelitian ini adalah perlakuan lama ekstraksi 8 menit MAE dengan kadar sisa pelarut paling rendah.

\section{KESIMPULAN}

Kondisi terbaik dalam memproduksi ektrak teh putih dengan menggunakan metode MAE dicapai pada penggunaan lama waktu ekstraksi 8 menit dengan level daya $70 \%$ dengan nilai polifenol mencapai $1,30 \mathrm{mg}$ asam galat/g berat kering bahan. Perbedaan penggunaan lama waktu pada proses ekstraksi mempengaruhi mutu ekstrak memberikan hasil terbaik yaitu kadar polifenol sebesar 1,2986 $\mathrm{mg} / \mathrm{g}$; nilai rendemen total terbaik sebesar $29,14 \%$, nilai bobot jenis filtrat 0,8058 ; bobot jenis ekstrak sebesar 1,1028; dan kadar sisa pelarut 45,33\%. 


\section{DAFTAR PUSTAKA}

Calinescu, I., Ciuculescu, C., Popescu, M., Bajenaru, S., \& Epure, G. 2001. Microwaves Assisted Extraction of Active Principles from Vegetal Material. Romanian International Conference on Chemistry and Chemical Engineering, 12, 1-6.

Gadkari, P. V., Balaraman, M. 2015. Catechins: Sources, Extraction and Encapsulation: A Riview. Food and Bioproducts Processing, 93: 122-138.

Handayani, D. 2013. Optimasi Ekstraksi Ampas Teh Hijau (Camellia Sinensis) Menggunakan Metode Microwave Assisted Extraction Untuk Menghasilkan Ekstrak Teh Hijau. Universitas Indonesia. Jakarta

Ho, Chi-Tang, Lin, Jen-Kun, Shahidi. 2009. Nutraceutical Science and Technology. CRC Press. New York.

Hutching, J. B. 1999. Food Color and Appearance 2nd ed. Maryland: Aspen Pub

Jain, T., Jain, V., Pandey, R., Vyas, A., \& Shukla, S. S. (2009). Microwave Assisted Extraction for Phytoconstituents - An Overview. Asian Journal Research Chemistry, 1 (2), 19-25.

Lestari, T. Agnis, N., Mira, N. 2015. Penetapan Kadar Polifenol dan Aktivitas Antibakteri Ekstrak Etanol Daun Sintrong (Crassocephalum crepidiodes (Benth.) S. moore). Jurnal Kesehatan Bakti Tunas Husada, 13 (1): 107-112.

Mandal, V., Mohan, Y., \& Hemalatha, S. (2007, January-May). Microwave Assisted Extraction - An Innovative and Promising Extraction Tool for Medicinal Plant Research. Pharmacognosy Reviews, 1 (1), pp. 7-18

Rohdiana, D. 2015, Teh: Proses, Karakteristik dan Komponen Fungsionalnya. Foodreview. Indonesia. $10(8): 34-37$

Shahidi, F., Naczk, M. 2004. Phenolics in Food and Nutraceuticals. CRC Press. Boca Raton

Sharief, D. 2006. Optimasi Proses Ekstraksi dan Pengeringan Semprot Pada Teh Hijau Instan [Skripsi]. Institut Pertanian Bogor. Bogor.

Siringo-ringo, M. P. 2006. Optimasi Ekstraksi Polifenol Teh Hijau Berdasarkan Ukuran Butir, Nisbah Bahan Baku-Pelarut dan Waktu [Skripsi]. Institut Pertanian Bogor. Bogor.

Suyatma. 2009. Diagram Warna Hunter (Kajian Pustaka). Jurnal Penelitian Ilmiah Teknologi Pertanian. Bogor: Institut Pertanian Bogor

Suzuki, M., Sano, M., Yosidha, R., Degawa, M., Mitase, T and Yamamoto, M.M. 2003. Epimerization of Tea Catechin and O-Methylated Derivatives of (-)-Epigallocatechin-3- O-gallate: Relationship Between Epimerization and Chemical Structure. J. Agric. Food Chem. 51: 510-514

Zhen, Yong-su, Chen, Zong-mao, Cheng, Shu-jun, Chen, Miao-Ian. 2002. Tea Bioactivity and Therapeutic Potential. Taylor \& Francis: London 